\title{
HABITAT USE BY PERSIAN GAZELLE (GAZELLA SUBGUTTUROSA SUBGUTTUROSA) IN BAMOO NATIONAL PARK DURING AUTUMN AND WINTER
}

\author{
${ }^{1}$ Haniyeh Nowzari, ${ }^{2}$ Behrouz Behrouzl Rad, ${ }^{3}$ Mahmoudreza Hemamı \\ Department of Environmental Science ,Faculty of Natural resources, \\ Tarbiat Modares University, Tehran, IRAN. \\ ${ }^{1}$ Corresponding author. Department of Environmental Science, Islamic Azad University of \\ Arsanjan, Fars, IRAN. hnowzari@yahoo.com \\ 2 Department of Environmental Science ,Faculty of Natural resources, Tarbiat Modares \\ University, Tehran, IRAN. behrouzi@modares.ac.ir \\ ${ }^{3}$ Department of Environmental Science ,Faculty of Natural resources, Sanati Isfahan
}

University, Isfahan, IRAN. mhemami@uea.ac.uk

RESUMEN

Como una especie amenazada, las poblaciones de gacela Iraní han disminuido durante las décadas pasadas. El conocimiento de la ecología de la gacela que incluye sus hábitos alimentarios y las asociaciones del habitat que utiliza son centrales para cualquier tipo de esfuerzo de conservación. La ecología de gacelas es pobremente conocida y las asociaciones del habitat de ésta y otras especies de gacelas no se han estudiado en Irán. La gacela Iraní en el habitat de 6000 ha (en el Parque Nacional de Bamoo ) se estudió durante el periodo de Otoño e Invierno. El uso del habitat fue relacionado con las comunidades de vegetación y su composición, por medio del conteo de los grupos fecales cada dos meses: de septiembre/ octubre 2004 a marzo/abril 2005, en 15 transectos permanentes de $2.5 \times 200$ metros que se localizaron al azar. La densidad de los grupos fecales fue muy similar en cuatro comunidades vegetales, mientras en la comunidad vegetal 1 en la que Scariola orientalis era dominante, fue significativamente menor. La densidad de gacelas está positivamente asociada con tres especies de arbustos (especie: Astragalus spp., Ebenus stellata, Achillea eriophora con $\mathrm{P}<0.01, \mathrm{P}<0.05, \mathrm{P}<0.05$, respectivamente) y dos especies de pasto (Poa bulbosa y Aegilops umbellulata, $\mathrm{P}<0.05$ ) y negativamente asociada con Helichrysum leucocephalum $(P<0.01)$, Scariola orientalis $(P<0.01)$ y Centaurea virgata $(P<0.01)$. Las observaciones acerca de la conducta alimentaria mostraron que las gacelas consumían Bromus danthoniae y Stipa barbata durante el otoño y Astragalus spp., Poa bulbosa, Aegilops umbellulata y Bromus danthoniae durante el invierno.

Palabras Clave: Uso del habitat, gacela Iraní, hábitos alimentarios, Parque Nacional de Bamoo .

\section{ABSTRACT}

As a threatened species populations of Persian gazelle have been declining within the country over the last few decades. The knowledge of gazelle ecology including their feeding habits and habitat associations is central to any kind of conservation effort. The ecology of gazelles in Iran is poorly known and habitat associations of this or other species of gazelles have not been studied in Iran. Habitat use by Persian gazelle was studied over autumn-winter period in its 6000 ha habitat in Bamoo National Park. Habitat use was related to plant communities and vegetation composition by clearance transect pellet group counts carried out every 2 months from September/October 2004 to March/April 2005 using 15 randomly placed $2.5 \times 200$ m permanent transects. The density of pellet groups was similar in 4 out of 5 
Nowzari et al.: Habitad use by persian gazelle

plant communities, while in plant community 1 , in which Scariola orientalis was the dominant species, it was significantly lower. The density of gazelles was positively associated with three species of bushes (Astragalus spp., Ebenus stellata, Achillea eriophora, $\mathrm{P}<0.01, \mathrm{P}<0.05, \mathrm{P}<0.05$ respectively) and two species of grass (Poa bulbosa and Aegilops umbellulata, $\mathrm{P}<0.05$ ) and negatively associated with trichomic Helichrysum leucocephalum $(P<0.01)$, thorny Scariola orientalis $(P<0.01)$, as well as both trichomic and thorny Centaurea virgata $(P<0.01)$. Observations on feeding behaviour showed that gazelles feed on Bromus danthoniae and Stipa barbata during autumn and Astragalus spp., Poa bulbosa, Aegilops umbellulata, and Bromus danthoniae over winter.

Key Words: Habitat use, Persian gazelle, Feeding habits, Bamoo National Park.

\section{INTRODUCTION}

The Persian gazelle Gazella subgutturosa subgutturosa ranges from east Turkey, to Iran, Pakistan, Turkmenistan and Central Asia (Mohammed et al. 2000), and it is currently categorized Near Threatened (NT) and if conservation efforts are not implemented for this species in the near future, it could change to the Vulnerable(VU) category (Mallon 2003).

One of the ecological concepts is habitat use. Theories or models of habitat use strive to capture the essentials of resources allocation by an organism and its implications for fitness (Lawes \& Nanni 1993); In other words, habitat use means finding relationships between an organism and its habitat factors.

Radio telemetry, pellet-group count, track count and direct observation are methods used commonly to measure habitat use by large ungulates (Weckerly \& Ricca 2000). However radio telemetry can be expensive and needs advanced transmitters and other equipment (Weckerly \& Ricca 2000). Track counts are not useful during autumn and winter when the weather is unstable, and rain and snow is common, and colder temperatures tend to reduce the activities of ungulates (Mooty \& Karns 1984). Direct observation is time consuming and the results are rarely accurate (Harkonen \& Heikkila 1999). On the other hand, those studies in which the use of pellet-groups have been compared, at the same time, with some other techniques (direct observation, track count and radio tracking), the results did not differ significantly between methods (Cairns \& Telfer 1980, Leopold et al. 1984, Loft \& Kie 1988). Therefore, pellet-group counting is a more effective and less expensive method for this purpose. It is a common method for assessing population trends and habitat use of wild ruminants (Palmer \& Truscott 2003, Rollins et al. 1984, Takatsuki 1991, Weckerly \& Ricca 2000) and has been used since the 1940s (Neff 1968). The data concerning habitat utilization can be used for the management of ungulate populations and their habitat essentials (Hemami et al. 2004, Suring \& Vohs 1979).

The Persian gazelle was still seen in most plains of Iran during late 1350s (1970s) but is now extinct in all non-protected areas, occurring only in protected areas, such as the Bamoo National Park managed by the Iran Department of the Environment (Ziaie 1996). The Persian gazelle is one of the most important species of this National Park, occurring in its open steppes. Nowadays overgrazing by livestock in gazelle habitats, conversion of these habitats to agriculture as well as over-hunting, are the most significant 
factors threatening the survival of Persian gazelles in this National Park. These factors are responsible for the decline in their habitat, absolute populations as well as population densities (Farhang Dareshoori, 1992).

In spite of these issues, no research has carried out on Persian gazelles in Bamoo National Park to gather data on their habitats, feeding habits and breeding. Therefore, we attempted to study habitat use by Persian gazelles, using clearance transect pelletgroup counts, and to determine factors affecting their use of habitat. We investigated habitat associations of this species in relation to plant communities and vegetation composition. The findings are useful for gazelle management.

\section{MATERIALS AND METHODS}

Study area. Bamoo National Park is located north of Shiraz city in Fars province, between $29^{\circ} 36^{\prime} 24^{\prime \prime}$ and $29^{\circ} 53^{\prime} 12^{\prime \prime} \mathrm{N}$ and $52^{\circ} 29^{\prime} 37^{\prime \prime}$ and $52^{\circ} 54^{\prime} 12^{\prime \prime} \mathrm{E}$. The western section of Park, with an area of 12000 ha, is not effectively protected, and the habitats are degraded, and now has no large mammals. Only the eastern section of Park, with an area of 36000 ha, provides relatively suitable conditions and is adequately protected (Razi 1994).

This National Park contains areas of Irano-Turanian Mountain and Irano-Turanian Plain (ITM,ITP), in the Zagros mountain chains. Its maximum and minimum elevations are the summit of Bamoo Mountain and the adjacent plains of the Park at approximately $2661 \mathrm{~m}$ and $1650 \mathrm{~m}$ altitude, respectively. This area has a semi-arid climate with warm, dry summers and cold, humid winters. The annual average precipitation and temperature are $338.9 \mathrm{~mm}$ and $17.07^{\circ} \mathrm{C}$, respectively. The three main landscape features are: mountains, hills and plains. As the height of the Zagros mountains decreases in Fars province, and distances increase between them, a number of plains such as Bamoo National Park occur. There are also varying sized plains between the mountain chains within this Park that form good habitats for wildlife. The Chahmahaki Plain (study area) is the largest plain in the Park, with an area of $60 \mathrm{~km}^{2}$ (6000 ha), and is one of the most important habitats of the Park because of large numbers of springs and watering places and desired vegetation cover. In addition it is secure and undisturbed because it is in the center of the Park. Therefore, it is the ideal habitat for gazelles in Bamoo National Park. The foothills of the mountains next to the plains are habitats particularly suited to gazelles and sheep (Razi 1994).

The total number of gazelles in Bamoo National Park estimated by direct observation at the beginning of the Mehr 1383 (Sep. / 2004) was 204 individuals.

Habitat structure. There are five main vegetation communities in the Chahmahaki Plain that were considered as five habitat types:

Vegetation community 1 (Habitat 1): Scariola orientalis/ Astragalus spp./ Ebenus stellata/ Achillea eriophora/ Centaurea virgata. 
Nowzari et al.: Habitad use by persian gazelle

Vegetation community 2 (Habitat 2.): Astragalus spp./ Artemisia aucheri.

Vegetation community 3 (Habitat 3): Astragalus spp./ Ebenus stellata/ Stipa barbata/ Helichrysum leucocephalum/ Scariola orientalis.

Vegetation community 4 (Habitat 4): Astragalus spp./ Ebenus stellata/ Stipa barbatal Artemisia aucheri/ Acantholimon scorpius.

Vegetation community 5 (Habitat 5): Astragalus spp./ Stipa barbata/ Ebenus stellata/ Acantholimon scorpius.

Transects. The transects were distributed by stratified random design, and the allocation of transects was randomly selected with three permanent transects $200 \mathrm{~m} \times 2.5 \mathrm{~m}$ being established for each habitat type (in total 15 permanent transects was established). As the aim of this study was to survey the habitat associations of gazelles in relation to vegetation communities, samples of index of vegetation variables from the study area were collected and identified.

Pellet-group counts. Our response variable to establish habitat use is based on fecal pellet-group counts in transects which were placed in different vegetation communities (Cransac \& Hewison 1997, Galindo et al. 1993, Guillet et al. 1995, Harkonen \& Heikkila 1999, Hemami et al. 2004, Hernandez et al. 1998, Homolka \& Matous 1999, Kearney \& Gilbert 1976, Koenen \& Krausman 2002, Lawes \& Nanni 1993, Loft \& Kie 1988, McCorquodale 1987, Morellet et al. 1996, Ogurlu 1996, Palmer \& Truscott 2003, Rollins et al. 1984, Secord et al. 1999, Suring \& Vohs 1979, Takatsuki 1991, Weckerly \& Ricca 2000, Welch et al. 1990, Zejda \& Homolka 1980). The fecal pellet-group counts were carried out during Autumn and Winter, because of declining food resources in cold seasons.

Because of the low decomposition rate of pellet-groups in arid areas, and considering the interval between removing and counting pellet-groups in forest areas with humid soils (two months, Hemami et al. 2004, two months, Lehmkuhl et al. 1994, three months, Welch et al. 1990), it was decided to count and clear pellet-groups every two months. The two-month accumulation period ensured that the number of pellet groups which were being accumulated in transects, were enough for statistical analyses. Therefore, accumulated pellet-groups within transects were counted and removed during Mehr 7-9 (Sep./Oct. 29-1), Azar 7-9 (Nov. 28-30), Bahman 7-9 (Jan. 27-29) and Farvardin 7-9 (Mar. 27-29) 1383-84 (2004-05).

Pellet-groups were defined as fecal clusters containing five or more individual pellets (Hemami et al. 2004). A pellet-group occurring on the edge of a transect, was counted if more than half of it was inside the transect. In order to achieve greater accuracy, pelletgroups were counted in each $20 \mathrm{~m} \times 1.25 \mathrm{~m}$ area of transect and then were removed completely from the transect. Index vegetation variables were also surveyed and the percentage cover of each of them was recorded in each $20 \mathrm{~m} \times 1.25 \mathrm{~m}$ area of the transect. After that, total numbers of pellet-groups and mean of percentage cover of index vegetation variables were calculated for each transect.

One new pellet-group as an "example pellet-group" was placed outside each transect, in order to study change, decay and decomposition rates and the possibility of their disappearance 
due to rain, snow and wind (Welch et al., 1990). Two months later, these example pellet-groups were re-surveyed and none of them had disappeared completely. Consequently, two-month periods were considered accurate and logical for the removal of pellet-groups.

A blind test for identifying gazelle and sheep pellet-groups was performed, and the surveyor achieved 95\% accuracy in the blind test before the first survey (Gazelle pelletgroups are different with sheep pellet-groups in size and shape).

For studying the feeding habits of Persian gazelle in Bamoo National Park, direct observation (Al-Hazmi \& Ghandour 1992, Goodson et al. 1991, Grettenberger \& Newby 1986, Holechek et al. 1982, Mendelssohn et al. 1997, Mendelssohn et al. 1995, Rominger et al. 1988, Saltz \& Ward 2000, Yom-Tov et al. 1995 ) was used as secondary method (beside pellet-group count method).

The grazing Gazelles were observed from a vehicle; with $8 \times 30$ Russian binoculars and we then went to the area and surveyed the grazed plants. As a gazelle's upper jaw does not have incisor or canine teeth, while separating leaves and stems of plants, some skin will remain on the unseparated parts and the plants eaten by gazelles can be recognized. All the plants grazed by gazelles were noted.

Analysis. Normality and Levene tests were first used to test data from normality of distribution of frequency and homogenity of variance. So, $\log _{10}$ transformed pellet-group density and square root transformed vegetation variables were used for statistical analyses, because data of pellet-group density and percentage cover of vegetation were not normal (Hemami et al. 2004).

$\log _{10}$ transformed pellet-group density accumulated in five habitat types in each twomonth period were analyzed with One-way ANOVA to test if there are significant differences in the density of pellet groups between samples times, if significant differences were detected, we used multiple comparison tests (Tukey) (Hemami et al. 2004).

For each two-month period, correlations between $\log _{10}$ transformed pellet-group density and square root transformed vegetation variables were obtained by Pearson correlation matrix and the minimal model was obtained by backward elimination, with variable retention judged by significance of the change in residual deviance (Crawley 1993).

\section{RESULTS}

Vegetation composition of the habitats: Figure 1 shows mean \pm S.E. of percentage cover of vegetation variables in each habitat type during six-month period. Cover of Helichrysum, Scariola, Centaurea and Helianthemum are highiest in habitat 1 and cover of Astragalus, Stipa, Ebenus, Graminae, Achillea and Bromus are high in habitat 5, 4, 3 and 2 .

Assessing habitat use in different months: Figure 2 shows the relative use of different habitats by gazelles, based on their pellet-group density in each two-month period. The six-month mean indicates that overall, although gazelles use all habitats they use habitat 1 least, while they occur in higher densities in habitat 5, 4, 3 and 2. 
Nowzari et al.: Habitad use by persian gazelle
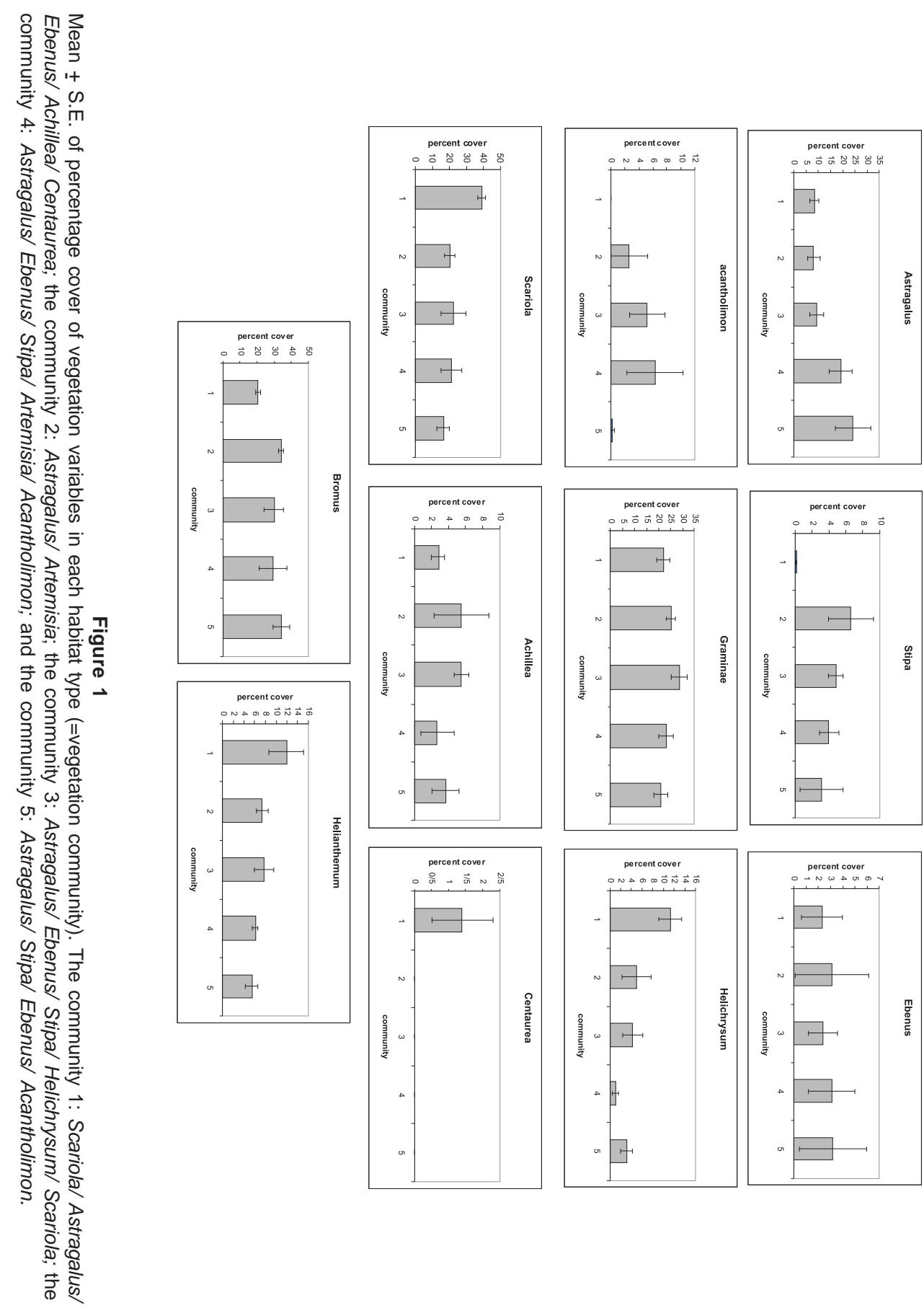

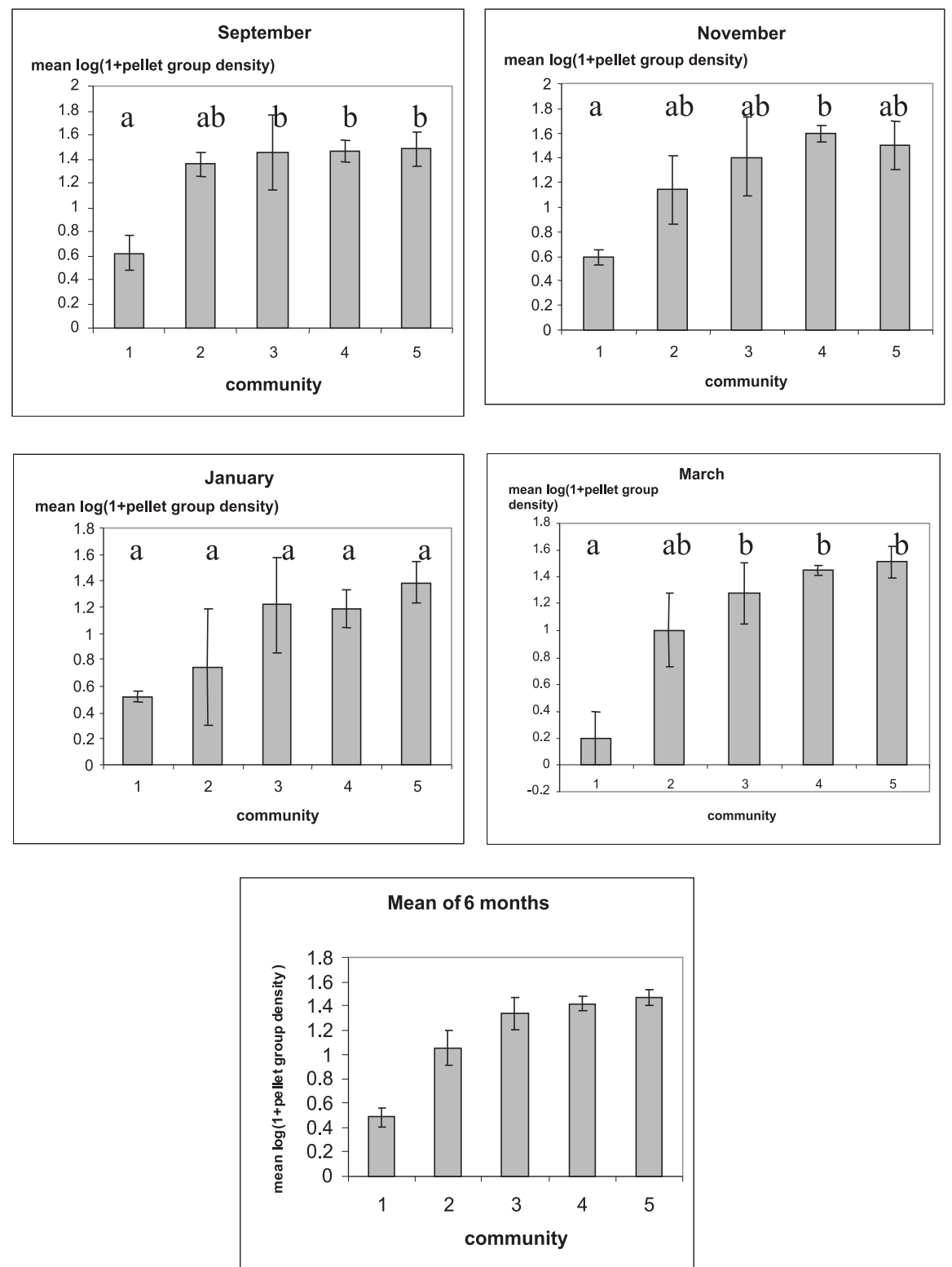

Figure 2

Log-transformed pellet-group density (mean+ S.E.) accumulated in different habitat type in pellet-group clearance transects in each 2-month-period, and the mean across all 6 months. The community 1: Scariola/ Astragalus/ Ebenus/ Achillea/ Centaurea; the community 2: Astragalus/ Artemisia; the community 3: Astragalus/ Ebenus/ Stipa/ Helichrysum/ Scariola; the community 4: Astragalus/ Ebenus/ Stipa/ Artemisia/ Acantholimon; and the community 5: Astragalus/ Stipa/ Ebenus/ Acantholimon. 
Nowzari et al.: Habitad use by persian gazelle

For each two-month-period the relative patterns of habitat use of gazelles were compared by analysis of variance of the ratio of pellet-group densities in each habitat type. The pattern of habitat use was significantly different in each two-month-period $(P<0.05)$, except for January $(P=0.2)$. Also, significant differences of pellet-group densities between habitat 1 and habitat 5, 4, 3 for September, habitat 1 and habitat 4 for November, and habitat 1 and habitat 5, 4, 3 for March was shown by Tukey test.

Table 1

Pearson correlation matrix for each bi-monthly survey; log-transformed accumulated pelletgroup density is related to square root transformed vegetation variables.

\begin{tabular}{|c|c|c|c|c|}
\hline $\begin{array}{l}\text { March } \\
\mathbf{P}\end{array}$ & $\begin{array}{c}\text { January } \\
\mathbf{P}\end{array}$ & $\begin{array}{c}\text { November } \\
\mathbf{P}\end{array}$ & $\begin{array}{c}\text { September } \\
\mathbf{P}\end{array}$ & \\
\hline & $(+) 0.006$ & $(+) 0.007$ & $\begin{array}{c}(+) 0.02 \\
(+) 0.046\end{array}$ & $\begin{array}{c}\text { Astragalus, pellet group } \\
\text { Stipa, pellet group } \\
\text { Ebenus, pellet group } \\
\text { Acantholimon , pellet group }\end{array}$ \\
\hline$(-) 0.004$ & $(-) 0.005$ & $\begin{array}{l}(-) 0.007 \\
(-) 0.002\end{array}$ & $\begin{array}{l}(-) 0.001 \\
(-) 0.001\end{array}$ & $\begin{array}{l}\text { Helichrysum, pellet group } \\
\text { Scariola, pellet group } \\
\text { Achillea, pellet group }\end{array}$ \\
\hline $\begin{array}{l}(-) 0.001 \\
(+) 0.010\end{array}$ & & $(-) 0.047$ & $\begin{array}{l}(-) 0.049 \\
(+) 0.036\end{array}$ & $\begin{array}{c}\text { Centaurea, pellet group } \\
\text { Bromus, pellet group } \\
\text { Graminae, pellet group }\end{array}$ \\
\hline$(-) 0.015$ & & & & Helianthemum, pellet group \\
\hline
\end{tabular}

* Correlations that were significant $(P<0.05)$

** Correlations that were significant $(P<0.01)$

Significant relationships between the pellet-group density and vegetation variables by Pearson correlation matrix are given in Table 1. The results show that pellet-group density showed significant associations with Astragalus in all periods except March, with Stipa in September, with Helichrysum in all periods, with Scariola in September and November, with Centaurea in all periods except January, with Bromus in September and March and with Helianthemum in March.

Gazelle minimal models of habitat use are given in Table 2. The results show that gazelle pellet-group density showed significant positive associations with Astragalus, Ebenus, Achillea and Graminae in January and with Ebenus in March. In addition gazelle pellet-group density showed significant negative associations with Helichrysum in September and November, with Scariola in November and with Centaurea in March.

The feeding habits of gazelles was studied by direct observation method $(8 \times 30$ Russian binoculars) during Autumn and Winter. Observation on grazed plants showed that gazelles mostly feed on surviving fresh green leaves/stems with dried yellow leaves/ stems of Bromus danthoniae and Stipa barbata (both from Graminae family) during Autumn, and green leaves/stems of two species of annual Graminae (Poa bulbosa and Aegilops umbellulata), yellow leaves/stems of Bromus danthoniae and also green leaves 
of annual Astragalus spp. (from Fabaceae family) and its pods, which are good sources of protein, over Winter.

Table 2

Gazelle minimal models of habitat use for each bi-monthly survey; log-transformed accumulated pelletgroup density is related to square root transformed vegetation variables.

\begin{tabular}{|c|c|c|c|c|}
\hline $\begin{array}{l}\text { March } \\
\mathbf{P}\end{array}$ & $\begin{array}{c}\text { January } \\
\mathbf{P}\end{array}$ & $\begin{array}{c}\text { November } \\
\mathrm{P}\end{array}$ & $\begin{array}{c}\text { September } \\
\mathbf{P}\end{array}$ & \\
\hline \multirow{4}{*}{$\begin{array}{c}0.028^{*} \\
(+0.20 \pm 0.081)\end{array}$} & $\begin{array}{c}000^{* *} \\
1(+0.46 \pm 0.086)\end{array}$ & & & Astragalus \\
\hline & & & & Stipa \\
\hline & $\begin{array}{c}0.020^{*} \\
(+0.22 \pm 0.080)\end{array}$ & & & Ebenus \\
\hline & & & & Acantholimon \\
\hline \multirow{6}{*}{$\begin{array}{c}000^{* *} \\
(-0.97 \pm 0.193)\end{array}$} & & $\begin{array}{c}0.008^{* *} \\
(-0.20 \pm 0.063) \\
0.003^{* *}\end{array}$ & $\begin{array}{c}0.001^{* *} \\
(-0.25 \pm 0.059)\end{array}$ & Helichrysum \\
\hline & $\begin{array}{c}0.025^{*} \\
(+0.30 \pm 0.113)\end{array}$ & $(-0.23 \pm 0.063)$ & & $\begin{array}{l}\text { Scariola } \\
\text { Achillea }\end{array}$ \\
\hline & & & & Centaurea \\
\hline & & & & Bromus \\
\hline & $\begin{array}{c}0.014^{*} \\
(+0.40 \pm 0.136)\end{array}$ & & & Graminae \\
\hline & & & & Helianthemum \\
\hline 0.26 & 0.58 & 0.53 & 0.43 & Adjusted $\mathrm{R}^{2}$ \\
\hline
\end{tabular}

$1(\mathrm{~B} \pm$ S.E. $)$

* Variables that were significant $(P<0.05)$

** Variables that were significant $(P<0.01)$

Other available food sources for gazelles are in the gardens and agricultural fields around the Park (beside habitat 5). These areas attract gazelles because of the existence of wheat, wild alfalfa, green wild forage and artificial water sources.

\section{DISCUSSION}

Our results of the habitat use survey show significant differences between habitats based on mean pellet-group density of gazelles in each two-month-period. Higher densities of gazelles were in habitat 5, 4, 3 and 2 during the six-month-period. Habitat 5, 4, 3 and 2 are the most suitable food habitats for gazelles because they had higher densities of Astragalus, Bromus, Stipa and two species of annual Graminae (Fig. 1) which are main food source for them; additionally habitat 5 is located beside the gardens and agricultural 
fields. They are also the most suitable resting habitats because of the higher densities of Ebenus and Astragalus (Fig. 1) which provide shelter.

Habitat 1 had lower densities of gazelles during the six-month-period (Autumn and Winter) because it had lower densities of the main food sources which are Bromus, Stipa, Astragalus and annual Graminae (Fig. 1), higher densities of trichomic Helichrysum and thorny Scariola (Fig. 1), lower densities of the main shelter which are Astragalus and Ebenus (Fig.1), lower densities of non-trichomic Achillea (Fig. 1), highest densities of trichomic and thorny Centaurea (Fig. 1), higher densities of Helianthemum (Fig.1), which grow in late winter and has trichomic leaves (Ghahreman 1982) and it is poisonous and exists in list of poisonous plants of Iran (Moghadam 1998); thus habitat 1 is used to a much lesser extent in March than other habitats.

Compared with three other periods, the lowest pellet-group densities were recorded in transects in January because gazelles are mating during this period (from November to December) and male gazelles probably feed less as they are mostly defending females (Fig. 2). In addition, densities of gazelles are similar in 5 habitat types during this period (January) because the male gazelle is territorial during mating time keeping other males out of its territory; consequently all areas are occupied by territorial males and their females (Fig. 2).

\section{CONCLUSION}

This is the first study in Iran to present data on habitat use by Persian gazelle in a plain over a six-month-period. Spatial and temporal variability in vegetation/habitat use is common for many free-ranging herbivores across the world, and possible causes and consequences have formed the subject of much research (Palmer et al., 2003). This study shows that gazelles use habitats 5, 4, 3, 2 and 1 during Autumn and Winter and they occur in higher densities in habitat 5, 4, 3 and 2 which provide more food, shelter and resting place together, while they show lower use of habitat 1 which has fewer food sources, shelter and resting place and the largest number of trichomic and thorny plants including Helichrysum, Scariola, and Centaurea. Therefore, habitat type affects densities of gazelles and their habitat use. Gazelles showed avoidance of trichomic Helichrysum and thorny Scariola as well as both trichomic and thorny Centaurea. They showed significant preferences for Astragalus and Ebenus for food and shelter, annual Graminae (Poa bulbosa and Aegilops umbellulata) for food, and non-trichomic Achillea.

The results of studies on the feeding behaviour of some species of Gazella show that they can alter their foraging strategy according to environmental conditions during different seasons and years (Ward \& Saltz 1994). According to data from direct observations, this study found that gazelles feed on leaves and stems of Bromus danthoniae and Stipa

barbata during Autumn and leaves and stems of two species of annual Graminae (Poa bulbosa and Aegilops umbellulata), leaves and stems of Bromus danthoniae, and leaves and pods of annual Astragalus spp. over Winter. Therefore, as has been found by previous authors (Ajami 2002, Hemami 1994), the species of Graminae family are important foods for gazelles. 
There is a need for further studies of habitat use by gazelles over a complete year, or several years, habitat use by gazelles in other protected areas in Iran, as well as greater understanding of plants avoided by gazelles because of their palatability and chemical composition.

\section{ACKNOWLEDGEMENTS}

We are grateful to the staff of Bamoo National Park for permission to work in it, Kh.Ahmadi and S.Azadi for assistance in the field, Dr Khosravi for identifying the samples of vegetation, $\mathrm{Dr}$ Groves, Dr Palmer, Dr Lawes and Dr Ward for copies of their papers, and F.Karimi and J.A Burton for useful suggestions that improved the manuscript. Haniyeh Nowzari would like to thank her parents for their support.

\section{LITERATURE CITED}

Ajami, H. 2002. Estimating food carrying capacity of gazelle's habitat in Kolahghazi National Park, Isfahan. M.Sc. thesis. Faculty of Natural Resources, Karaj, Tehran University.

Al-Hazmi, M.A. \& A.M. Ghandour. 1992. An ecological study of gazelles in the western and southern regions of Saudi Arabia. J. Arid Environ. 23:279-286.

Cairns, A.L. \& E.S. Telfer. 1980. Habitat use by 4 sympatric ungulates in boreal mixed wood forest. J. Wildl. Manage. 44:849-857.

Cransac, N. \& A.J.M. Hewison. 1997. Seasonal use and selection of habitat by Mouflon (Ovis gmelini): Comparison of the sexes. J. Behav. Proc. 41(1):57-67.

Crawley, M.J. 1993. GLIM for Ecologists. Blackwell Scientific Publications, Oxford.

Farhang Dareshoori, B. 1992. Bamoo National Park. First ed. Department of the Environment Press, Tehran, Iran.

Galindo, L.C., G.A. Morales \& R.M. Weber. 1993. Distribution and abundance of Coues deer and Cattle in Michilia Biosphere Reserve, Mexico. Southwest. Nat. 38(2):127-135.

Ghahreman, A. 1982. Iran colored flora. Research Institute of Forests and Ranges Press with corporation of Department of the Environment Press, Tehran, Iran.

Goodson, N.J., D.R. Stevens \& J.A. Bailey. 1991. Effects of snow on foraging ecology and nutrition of Bighorn sheep. J. Wildl. Manage. 55(2):214-222.

Grettenberger, J.F. \& J.E. Newby. 1986. The status and ecology of the Dama gazelle in the Air and Tenere National Nature Reserve, Niger. Biol. Conser. 38(3):207-216.

Guillet, C., R. Bergstrom, G. Cederlund, J. Bergstrom \& P. Ballon. 1995. Comparison of telemetry and pellet-group counts for determining habitat selectivity by Roe deer (Capreolus capreolus) in winter. J. Gibi. Faun. Sau. 12(4):253-269.

Harkonen, S. \& R. Heikkila. 1999. Use of pellet group counts in determining density and habitat use of moose (Alces alces) in Finland. J. Wildl. Biol. 5(4):233-239.

Hemami, M.R. 1994. Distribution of gazelles in Iran. M.Sc. thesis. Faculty of Natural Resources, Karaj, Tehran University.

Hemami, M.R., A.R. Watkinson \& P.M. Dolman. 2004. Habitat selection by sympatric Muntjac (Muntiacus reevesi) and Roe deer (Capreolus capreolus) in a lowland commercial pine forest. J. For. Ecol. Manage. 194:49-60.

Hernandez, L., H. Barral \& C.S. Sanchez. 1998. Are scats and radiotelemtry data similar indicators of habitat use? Acta Zool. Mex. (n.s.)75:117-123. 
Nowzari et al.: Habitad use by persian gazelle

Holechek, J.L., M. Vavra \& R.D. Pieper. 1982. Botanical composition determination of range herbivore diets: A review. J. Rang. Manage. 35(3):309-315.

Homolka, M. \& J. Matous. 1999. Density and distribution of Red deer and Chamois in subalpine meadow habitats in the Jeseniky mountains (Czech Republic). J. Fol. Zool. 48(1):1-10.

Kearney, S.R. \& F.F. Gilbert. 1976. Habitat use by White-tailed deer and Moose on sympatric range. J. Wildl. Manage. 40(4):645-657.

Koenen, K.K.G. \& P.R. Krausman. 2002. Habitat use by desert Mule deer in a semidesert grassland. J. Southwest. Nat. 47(3):353-362.

Lawes, M.J. \& R.F. Nanni. 1993. The density, habitat use and social organisation of Dorcas gazelles (Gazella dorcas) in Makhtesh Ramon, Negev desert, Israel. J. Arid Environ. 24(2):177-196.

Lehmkuhl, J.F., C.A. Hansen \& K. Sloan. 1994. Elk pellet-group decomposition and detectability in coastal forests of Washington. J. Wildl. Manage. 58(4):664-669.

Leopold, B.D., P.R. Krausman \& J.J. Hervert. 1984. Comment: the pellet-group census technique as indicator of relative habitat use. Wildl. Soc. Bul. 12:325-326.

Loft, E.R. \& J.G. Kie. 1988. Comparison of pellet-group and radio triangulation methods for assessing Deer habitat use. J. Wildl. Manage. 52(3):524-527.

Mallon, D.P. 2003. Gazella subgutturosa in 2003 IUCN red list of threatened species. www.redlist.org .

McCorquodale, S.M. 1987. Fall-winter habitat use by Elk in the shrub-steppe of Washington USA. J. Northwest. Sci. 61(3):171-173.

Mendelssohn, H., C.P. Groves \& B. Shalmon. 1997. A new subspecies of Gazella gazella from the southern Negev. Israel J. Zool. 43:209-215.

Mendelssohn, H., Y. Yom-Tov \& C.P. Groves. 1995. Gazella gazella. Mammal. Speci. 490:1-7.

Moghadam, M. 1998. Range \& Range management. First ed. Tehran University Press, Tehran Iran.

Mohammed, O.B., A.J. Davies, H.S. Hussein \& P. Daszak. 2000. Gazella subgutturosa marica at the King Khalid Wildlife Research Centre, Thumammah, Saudi rabia. Vet. Rec.146: 2-218.

Mooty, J.J. \& P.D. Karns. 1984. The relationship between White-tailed deer track counts and pellet-group surveys. J. Wildl. Manage.48(1):275-279.

Morellet, N., B. Guibert, F. Klein \& C. Demolis. 1996. Forest habitat use by Red deer (Cervus elaphus) in the Is-sur-Tille massif(Cote-dOr). Gib. Faun. Sauv.13(4):1477-1493.

Neff, D.J. 1968. The pellet-group count technique for big game trend, census and distribution: a review. J. Wildl. Manage. 32:597-614.

Ogurlu, I. 1996. Habitat use of Red deer (Cervus elaphus) in Catacik forest. Turkish J. Zool. 20(4):427-435.

Palmer, S.C.F., A.J. Hester, D.A. Elston, I.J. Gordon \& S.E. Hartley. 2003. The perils of having tasty neighbors: Grazing impacts of large herbivores at vegetation boundaries. J. Ecol. 84(11):2877-2890.

Palmer, S.C.F. \& A.M. Truscott. 2003. Seasonal habitat use and browsing by Deer in Caledonian pinewoods. J. For. Ecol. Manage. 174(1-3):149-166.

Razi, M. 1994. Bamoo National Park. Fars Department of the Environment Press, Shiraz, Iran.

Rollins, D., F.C. Bryant \& R. Montandon. 1984. Fecal pH and defecation rates on 8 ruminants fed known diets. J. Wildl. Manage. 48(3):807-813.

Rominger, E.M., A.R. Dale \& J.A. Bailey. 1988. Shrubs in the summer diet of Rocky mountain Bighorn sheep. J. Wildl. Manage. 52(1):47-50. 
Saltz, D. \& D. Ward. 2000. Responding to a three-pronged attack: Desert lilies subject to herbivory by Dorcas gazelles. J. Plant Ecol. 148:127-138.

Secord, M.L., P.E. Zager \& D.H. Pletscher. 1999. The influence of temporal and spatial factors on clearcut use by White-tailed deer in northern Idaho. West. J. Appl. Fores. 14(4):177-182.

Suring, L.H. \& P.A.J. Vohs. 1979. Habitat use by Columbian white-tailed deer (Odocoileus virginianus leucurus). J. Wildl. Manage. 43(3):222-225.

Takatsuki, S. 1991. An application of fecal pellet count to an area of known density of Sika deer. J. Hony. Kaga. 30(2):191-196.

Ward, D. \& D. Saltz. 1994. Foraging at different spatial scales: Dorcas gazelles foraging for lilies in the Negev desert. J. Ecol. 75(1):48-58.

Weckerly, F.W. \& M.A. Ricca. 2000. Using presence of sign to measure habitats used by Roosevelt elk. Wild. Soc. Bull. 28(1):146-153.

Welch, D., B.W. Staines, D.C. Catt \& D. Scott. 1990. Habitat usage by Red (Cervus elaphus) and Roe (Capreolus capreolus) deer in a Scottish sitka spruce plantation. J. Zool. Lond. 221:453-476.

Yom-Tov, Y., H. Mendelssohn \& C.P. Groves. 1995. Gazella dorcas. Mammal. Spec. 491:1-6.

Zejda, J. \& M. Homolka. 1980. Habitat selection and population density of Field roe deer (Capreolus capreolus) outside the growing season. J. Fol. Zool. 29(2):107-115.

Ziaie, H. 1996. A field guide to the mammals of Iran. First ed. Department of the Environment Press, Tehran, Iran.

Recibido: 27 de junio 2006

Aceptado: 8 de noviembre 2006 
